\title{
An Ecocritical Reading of Paul Bowles's The Sheltering Sky
}

\author{
Hossein Sheikhzadeh (Corresponding Author) \\ Department of Humanities, Saravan Branch, Islamic Azad University (IAU), Saravan, Sistan and Balochistan, Iran \\ E-mail: behz2000@gmail.com \\ Abdolghafour Bejarzehi \\ Department of Humanities, Nikshshahr Branch, Islamic Azad University (IAU), Nikshahr, Sistan and Balochistan, Iran \\ E-mail: abejarzehi@gmail.com
}

Received: 22-03-2017

Published: 01-09-2017
Accepted: 15-05-2017

doi:10.7575/aiac.ijalel.v.6n.5p.232
Advance Access Published: July 2017

URL: http://dx.doi.org/10.7575/aiac.ijalel.v.6n.5p.232

\begin{abstract}
Landscapes are not simply something objective and unchallenged out there but the work of the mind made by the strata of memory. This paper attempts to show that an ecocritical reading of Paul Bowles's The Sheltering Sky (1949) helps one in better understanding of this novel of post-colonial alienation and existential despair. Bowles is an American writer and a composer who is undoubtedly the most arresting example of cross-cultural influence concerning a Western author and the Middle East and North Africa. His fiction mostly focuses on American expatriates travelling in exotic locations. The Sheltering Sky is an encounter with the Sahara, not only the physical one but the desert of moral nihilism into which one may wander blindly. The boundless desert acts here as a metaphor and the journey symbolizes one's own journey into the depth of his/her soul. The desert also projects an apocalyptic vision in the struggle between the West and the East and the Sahara becomes in fact a Conradian Heart of Darkness, an Eliotian Waste Land, and a Sartrean No Exit. In the novel the actual environment becomes in some ways pale and covert under the psyche of the writer. Consequently we come to know that Bowles's own knowledge and awareness of the same environments left traces in his work. Accordingly we may wrap up that the environment bears a direct impact on our understanding of it.
\end{abstract}

Keywords: Mind, Landscape, Desert, Ecocriticism, The Sheltering Sky

\section{Literary Ecology and Paul Bowles}

Simply defined, literary ecology - as emerged in 1980s (in the USA) and 1990s (in the UK) - is the study of the relationship between literature and the physical environment and exploration of the ways that writing both reflects and influences our interactions with the natural world (Glotfelty \& Fromm, 1996). The approach which remained - until recently - closely focused on critical analyses of nature writing and literature of wilderness over the past decade received more attentions afterwards. Some writers like Kathleen R. Wallace and Karla Armbruster, for example, push well beyond that established framework. In their Beyond Nature Writing: Expanding the Boundaries of Ecocriticism, they support us even to explore the advantage of ecocritical approaches to the texts associated with metropolitan settings and "far "beyond nature writing"" as those of Henry James which are mostly related to European gathering salons and drawing rooms (Wallace \& Armbruster, 2001, p. 7). Such readings and approaches facilitate us to enhance the core activity of literary studies, literary interpretation, as well as our general understanding of literature's function. Easterlin likewise asserts in her "Cognitive Ecocriticism" that "the dynamic between human social relationships and physical places" can be understood through "literary representations" towards those nonhuman environments (2010, p. 272).

Accordingly in this paper we contend that the work of the American writer Paul Bowles can benefit a lot if such an ecocritical reading is applied to. His works are, at one level, mainly focused on American expatriates finding themselves unfit in exotic environments and on another level highlight the interaction of natural and cultural surroundings and their impact on human organism - the mind and the body of those individuals. On the other hand, Bowles's fiction portrays characters' conflicted emotions and cognitive processes with regard to their material presence in an unfamiliar place (Mossner, 2013, p. 220). Hence by such an ecocritical reading which embodies hints of cognitive science and environmental psychology we not only better realize the nature of Bowles's protagonists and interaction of their mind and body with exotic environments but we can also digest how Bowles's own nature, his background and recognition of those environments have left evidence in his fiction.

Our attempt can perhaps be at best exercised on one of Bowles's main novels, The Sheltering Sky (1949), which was also adapted into a notable 1990 film with the same title by the stellar director Bernardo Bertolucci. The first drafts of the book penned by the author while he was travelling in the arid lands of North Africa. Bowles despised mechanization, pollution, noise, wars, and western civilization and hence removed himself physically and 
If he wished to physically remain outside of his native country, he chose to remove himself psychologically as well. Bowles wrote that with their extremes of plant life, the desert and the jungle were the two landscapes that held the most power for him (Pounds, 1985, p 81).

As a result he established himself in Morocco in 1947, "because more than any other country it had been shut off from the modern world" and thereafter he became a sort of guru for Beat Generation (qtd. in Dillon, 2000, p. 145). In fact Bowles's detachment from America, his strong inclination for "exotic East" and preoccupation of "Moroccan thinking in his fiction" made writers like John R. Maier comment that among American writers Bowles's fiction is "by far the most striking example of cross-cultural influence involving a Western author and the Middle East and North Africa" (1996, p. 144). The novel follows a similar scenario. It is the portrayal of three Americans - a couple from New York along with their friend, Tunner - who suddenly and haphazardly - unprepared and unqualified - travel to the North African desert after World War II to resolve their marital problems and monotonous life. However, by their ignorance of the cruel nature, local culture and imminent dangers around them they soon were enmeshed by hard situations and the trip becomes treacherous - a Conradian Heart of Darkness and a Sartrean No Exit. And at the end the husband, Port, dies a terrible death because of typhoid, and the wife, Kit, goes through an incredibly intense psychological transformation which stops her from returning to American civilization.

There are two conspicuous scholarly articles which can be referred to as the literature of this study. Hout (2000) compares and contrasts Bowels's novel with Wilfred Thesiger's Arabian Sands and believes that "threats to the ecology? imposed by water, air, land, and noise pollution and those to human and cultural diversity, prompted Bowles and Thesiger to seek refuge in one place that had remained relatively protected from the winds of change in the late 1940s: the desert" (p. 113). Moreover, Mossner (2013) points out that we should not look at the desert in a simple way but as a metaphor for the psychological status of the characters.

\section{Desert as Setting}

The setting of the novel is, no doubt, as most researchers agree, largely the desert of the Sahara. Yet many critics do not admit the place as the real setting of the novel. In fact in Bowles's fiction in general and The Sheltering Sky in particular what is made prominent is the author's psychological inquiry and characters' mind. On the other hand, locales are often pale under the text. I argue that the novel is characters' search for meaning in a vast and bleak landscape. The boundless desert here acts as a character and in effect a metaphor and symbol for the characters' sterile psychological landscapes; this desert resembles basically "Conrad's jungle and Eliot's wasteland" (McInernev, 1993, p. 188). From one point the journey is, in effect, an expedition into the depth of our own soul, and perhaps an escape from the modern life - the gadgeted over-crowded megacities, towering blocks of buildings and flats, greed for quick profits, frustration and lack of security in such a world. The indifference, aridity, monotony and bleakness of desert mirror the same qualities in the love relationship of the couple while highlighting, on a larger scale, the isolation, meaninglessness and absurdity of the twentieth century relationships in the western world, and quest for self-destruction.

In this regard Bowles himself once called the novel "an adventure story, in which the actual adventures take place on two planes simultaneously: in the actual desert and in the inner desert of the spirit" (Stewart, 1974, p. 71; Birch \& Hooper, 2012, p. 82). Lacy and Poole hold that for Bowles "the land and peoples of north Africa" act as "effective physical symbols for essentially mental and emotional dialectics" (1996: 143). Gena Dagel Caponi admits this existential and post-colonial novel as "a travel book about an inner journey through states of consciousness" (1994, p. 127).

However such a psychoanalytical interiorization of the desert which has started, as Hout remarks, "[s]ince the heyday of existentialism in the 1950s and 60s," can be problematic for it robs the desert "of its historical and geographical particularities" (2000, p. 118). Highlighting Karen Barad and Joy Williams alert, Alaimo also laments that in our readings of nature and cultural texts

matter, the vast stuff of the world and of ourselves, has been subdivided into manageable 'bits' or flattened into a 'blank slate' for human inscription. The environment has been drained of its blood [and] its lively creatures . . . in order that it become a mere empty space . . for human 'development' (2010, pp. 1-2).

Consequently if one scrutinizes the covert layers of The Sheltering Sky s/he may discover that the physical wilderness is not completely off the track. Actually what Paul Bowles intends to underscore is that the main characters of the novel similarly attempt to understand the desert as a screen and an empty space onto which they can inscribe and mirror their own emotions, fears, desires and difficulties. The novel shows and warns of the problems and dangers that one may face if s/he try to compress or "flatten" the landscape into a "blank slate" and through this way the author flips our cognition, vision, understanding, emotional state and identity.

Nonetheless, such notions are not so straightforward; their embodiment goes back and forth between mind and matter, the imaginary and the symbolic, the subjective and the objective, the social and the ideological, and so on. On one hand the landscapes and "the external world" are not something out there but, as human geographer Denis Cosgrove holds, they are the mediation "through subjective human experience" (1998 [1984], p. 13). Or they are "always both objective physical place and a subjective cognized image of that place" (Tilley, 2006, p. 20). "Before it can ever be repose for the senses," opines Schama arguably, "landscape is the work of the mind. Its scenery is built up as much from strata of memory as from layers of rock" (1996, pp. 6-7). It is also true that an actual landscape affects 
inevitably our subjective image and the way we experience, think about or perceive it, especially when we are physically present in it. Our embodiment, "[i]dentities" and even our relations to straightforward other humans similarly "have their basis in the multiple ways in which we perceive and receive the world through all our senses" (Tilley, 2006, p. 22). In consequence, environmental psychology and cognitive science often interplay with ecocriticism.

All such interactions between mind, heart, body and the environment, as mentioned above, are crucial for an ecocritical reading of The Sheltering Sky. Emotions like fear, boredom, love, hate, ambiguity and the like which are the inherent qualities of the very desert are prevalent in the text. They show protagonists' interior conflicts as well as their understanding of the landscape - both of focal importance for the development of the plot. The Sahara bears real ideological and material impacts on the way people think and act. Bowles's own emotional relationship to the Sahara desert had a momentous impact on his novel.

Nature generates the stories we tell and what is interesting about Bowles in this regard is that the natural environments helping him in narrating his stories are not the places in which he grew and brought up, but the exotic locales he firstly faced as a traveller and later as a permanent inhabitant. He often describes the deep change he experienced when first travelled in the Sahara desert and hence underlines in his famous essay, "Baptism of Solitude", that "no one who has stayed in the Sahara for a while is quite the same as when he came" (2006 [1957], p. 134). Accordingly, he remarks: "I realized that I loved all those things: the sun, the silence, the nothingness. I had never been sure whether I liked those things. But in order to feel all that you have to be completely alone, far from the natives and the colonials" (qtd in Caponi, 1993, p. 225). Bowles further notes in another 1998 interview, "Let It Come Down", that "much of [his] fiction starts out with landscape in [his] head. First there is the scene, where it is laid. And then," if he is familiar with the place he knows "what can happen there, who can be in it, and what the influence of the place is on the protagonists" $(1998$, p. 1). According to him the type of story and the changes that plot and the characters undergo depend profoundly on the choice of landscapes.

\section{Major Characters' Interaction}

The relationship of Bowles's (often Western) characters with the natural world is noteworthy. Such a relationship varies among them and yet it differs tensely from the sense and feeling that the natives have towards the space and desert. The local inhabitants of the arid lands are often the ones who are accustomed to simple life, hunger, thirst, harshness, hardship and renunciation of carnal desires. In such lands, spiritual quest is often associated with the very suffering and toil. On the contrary, Westerners' futility and idleness of life and frequent sales talks made their spiritual quests in some ways pointless and deeply dull.

Port Moresby seems to be the only one character who reportedly understands the Sahara through his personal emotions and symbolic feelings as he had also travelled to North Africa before. He seems to be always in search of something and obsessed with movement, maps and new environments. According to Eaterlin this has been adaptive excitement of human being since the time of his ancestors (2010, p. 268). However, Port is aimless and indifferent to the imminent dangers and uncertainties they may face. Averting all the warnings against travel to French-occupied Africa, he trickily shows his wife some "carefully chosen collection of photographs" of the time before war when he was there (Bowles, 2005, p. 101). He also calls himself a traveller and not a tourist, the one who moves very slowly not with the mere plan of visiting a place or returning to his homeland. This, more or less, originates from his feeling of "unhomeliness," a term described by Bhabha as belonging to everywhere and nowhere (1992): Port cannot express "precisely where it was he had felt most at home" (Bowles, 2005, p. 6).

As suggested in the novel, Ports' fondness and interest to the Sahara originates from the following points: First, in his understanding the Sahara is an attractive place that is far away from the dull way of life in America and the hustle and bustle thereof. In fact he regularly supposes himself aloof and detached from the world of America and the West. Secondly, Port's original identity, as he proclaims, was associated with his ancestors who migrated and later came to the West wilderness and thus bore a collective identity. Disengaged from America and being proud of his nomadic existence, he was more satisfied with his pioneering dream to follow his ancestors' older tradition; it was his pleasure to visit foreign and exotic locales. He felt overconfident to visit a place after war which its tourism was

never well developed . . . but utterly destroyed by war . . . [This] made him feel that he was pioneering - he felt more closely identified with his great grandparents, when he was rolling along out here in the desert than he did sitting at home looking out over the reservoir in Central Park. (Bowles, 2005, p. 101)

Next it is Port's own subjective emotion, anxiety and fear of his gloomy past which constantly shimmers and anchored in the sea of his mind. To get rid of all such sentiments, he feels himself secure and sheltered in the remoteness and silence of this land. He finds the sky here "very strange", like "a solid thing up there" protecting him from darkness and "what's behind" (Bowles, 2005, p. 94). However he didn't realize the one fact that the natural and cultural environments exist utterly independent and indifferent to whatsoever projection a human may have in heart and mind. So instead of his influence over nature, environment affects his mind and body. Even the very sky, which the novel has been named after it, does not shelter them "from what's behind" and the couple gradually become more detached from each other.

Thus, "preoccupied with himself” (Alaimo, 2010, p. 164), Port's relationship to the natural environment is indicated by an ample amount of psychological projection, which is away from material dimension of such interaction and as a result he was arguably much like a tourist rather than a traveller. Similarly, one finds the couple's views towards the land's 
local Arabs and their culture as accompanied with a sense of contemptibility and inferiority. But in reality and within the realm and demarcation of their own tradition and civilization the simple natives seem to be superior.

The psychological gap between Port and Kit becomes wider and wider throughout the narrative. An ecocritical reading of the text also suggests that whenever the couple bears common attitudes and emotions to nature, they are happy and together: "As they approached, already they could see the endless flat desert beyond . . . [and] the sun was at the flat horizon ... [as] Kit took Port's hand. They climbed in silence, happy to be together" (Bowles, 2005, p. 92).

At another section Port loses his passport and feels unknown and anonymous in the desert; he is neither an American anymore, nor westernization and prestige can help him now: “It's strange,' he said with a deprecatory smile, 'how, ever since I discovered that my passport was gone, I've felt only half alive. But it's a very depressing thing in a place like this to have no proof of who you are, you know"' (Bowles, 2005, p. 154). Here he understands that without that piece of paper he cannot assert his Americanness, yet he is not able to neglect or reject completely this dependency which is obviously a part of his identity. He also could not construct himself to the North African world: returning to the hotel, he could not feel, interact with or confront the natural world, the azure sky and the vast vistas:

He did not look up because he knew how senseless the landscape would appear. It takes energy to invest life with meaning, and at present, his energy was lacking. . . . He did not want to face the intense sky, too blue to be real, above his head, the ribbed pink canyon walls that lay on all sides in the distance ... or the dark spots of the oasis below. They were there, and they should have pleased his eye, but he did not have the strength to relate them, either to each other or to himself; he could not bring them into any focus beyond the visual. So he would not look at them. (Bowles, 2005, pp. 154-5)

Thus one observes his faded, still strong, dependency to his Americanness and how loss of a paper affects his feeling and relationship to North African land negatively. The feeling continues afterwards and thence the nature and its creatures take even some more gothic characteristics to him: “. . . cold in September in the Sahara desert.' 'Well, it'll have to seem peculiar,' he said with annoyance. Then he suddenly exclaimed: 'These flies have claws . . ." (Bowles, 2005, p. 158). The scenario continues and the final bad luck is Port's symptom of typhoid fever which causes him severe physical decline.

Another major character of the novel is Port's wife, Kit. She is observed as not comfortable with the idea of travel to such a land from the beginning of the novel. It was her first journey to such a land and she was not prepared at all to confront its harsh, real nature. She was in fact misled by her husband's enchantment and well chosen photographs of eye-catching oases, hotels, lobbies and bazaars. However, the very reality was completely different from those images. Such a contradiction, later on, entirely repelled their intention of solving their marital problems to the extent that they get more detached from each other leading even to sexual adventures with others - Port with natives and Kit with their travelling friend Tunner, both yielding however to no satisfaction.

Not sharing his husband's enchantment, Kit's first reactions towards such a world were fear and utter boredom. The only things that could make her happy were Western consumer goods and luxurious amenities as she once changed the room in the hotel as a small bazaar, pointing to desert and saying to Port, “. . . 'I felt I'd simply die if I didn't see something civilized soon. ..." (Bowles, 2005, p. 155). Unlike Port she cannot adapt quickly, nor is she able to give up her Americanness: “After all, I am still an American you know. And I'm not able to be anything else'. . . ." (Bowles, 2005, p. 155). She acts as a stereotypical tourist in hurry and hopeful to return home soon.

Kit's first emotional reaction to the mere void and the fearful, empty North African desert is in some ways similar to what Haynes (1999) underscores in her book about early European travellers and their response to the Australian desert. Such a response which firstly comes from a cognitive sense of fear caused by the landscape makes Kit ready for a run, escape or flight. Thus Port's death opens the way up for such a flight and even transformation. Little by little, being utterly alone, she perceives that the desert is not a standstill and an empty place but what she herself created and in reality 'some part of this landscape was moving even as she looked at it' (Bowles, 2005, p. 220). The more she tried to grasp the ecological space around her, the more she felt needless of her American staffs to comfort her. She changes and surprisingly starts loving the arid land, the oases, their people and primitive cultures: "As the morning passed, the landscape took on a gaiety and softness that were not quite like anything Kit had ever seen. . . For the first time she felt a faint thrill of excitement. 'It is rather wonderful,' she thought, "to be riding past such people in the Atomic Age"” (Bowles, 2005, p. 179).

So she went to a nearby oasis where "[s]he kicked off her sandals and stood naked in the shadows. She felt a strange intensity being born within her. .." (Bowles, 2005, p. 240). Her thinking and feeling were transforming towards the harsh, now attractive and relaxing, nature: "Without hesitating she made for the nearest tree ad set her bag down. The feathery branches swept the sand on all sides of the trunk - it was like a tent" in which she could sleep (Bowles, 2005, p. 242).

Later she is picked up by Belqassim's Caravan and though being raped repeatedly and lived as a sex captive, disguised as a man and concealed from Belqassim's three views, she does not seem to be sad. She now feels pleased with the desert, the oases and the classic houses in villages while the blue and infinite sky shelters her from her real dread - the bitter memories of her past life and Port's death. In this respect Melling comments as follows:

In The Sheltering Sky, the privation of Kit, who nurses [Port] in his last days, are only relieved by the attentions of the living: the nomadic tribesmen who allow her to escape the isolation of $\mathrm{El} \mathrm{Ga'a}$ 
and join their caravan. The tribesmen rape her repeatedly, but Kit eschews alienation and finds herself attracted to the predatory sex of her captor, Belqassim. Belqassim's attention is compensation for her husband's physical incapacity and derangement in El Ga'a. In a landscape suffused with "an excrescence of hatred" (2001: 288) she experiences "a gnawing desire to be close" to someone, a yearning brought on not by the fear of the rape but the prospect of celibacy. (2001, p. 200)

Kit's disloyalty (to her deceased husband) in this context indicates a kind of freedom and going beyond boundaries and a dark past which leads to the threshold of surrealism in postmodernism. It actually shows her escape from her ownmade restrictions and leads to creation of another world with different moralities. After the Bedouin's wives discover the fact Kit escapes the house and founds her way to the American consulate in Oran. But surprisingly we find that at this point she cannot leave the Africa and return home; the English language and the way of people's speech now look bizarre to her. Ironically her American passport is the only proof she has of her identity but she left it for good.

Thus, Kit reaches a new sort of identity and seems strangely much happier now. Loss of her identity is perhaps connected somehow to Miss Ferry's remarks in the novel that nothing gets lost for good in the desert: "The desert's a big place, but nothing really ever gets lost there" (Bowles, 2005, p. 310). And in the end we see her wandering and thence disappearing through the streets of Oran, away from Western civilization. As Hout (2000) rejects some critics' views on Kit's insanity I also disagree with such a notion contending that Kit simply became someone else, a person between boundaries of sanity and madness - a deserted one who does not desert but enter (a new world).

\section{Conclusion}

Last but not least, the paper suggested that an ecocritical reading of Paul Bowles's The Sheltering Sky facilitates a better understanding of this novel of post-colonial alienation and existential despair as well as the characters' behaviour. It is shown that an environment affects one's emotion, cognition, behaviour, culture and relationship to other humans and there is often close interactions among all. On the other hand, there is a covert connection between the natural environment and the consciousness of man. This paves the ground for further explorations in the subjects of cognitive psychology, neuroscience and the like. The same is true as for the desert landscape: the Sahara bears real ideological and material impacts on the way people think and act and no one who has stayed there for a while returns the same as when he first enters. Such a study can be exceptionally conducive for exploration of human representation, understanding and perception of the natural world. In this respect, what Bowles's fiction attempts to represent is also twofold: they show how passion and feelings portray human attitudes and perceptions of particular environments as well as how those environments in turn influence human feelings, perceptions and views. As such Bowles's first and best-known novel The Sheltering Sky paints the same scenario and without such an ecocritical reading and exploration it is probable that one may fail to delve deep enough into the mind of the protagonists and hidden layers of the novel. So one can safely infer that what creates and forms The Sheltering Sky is an embodiment of the ecological space of the Sahara as well as the author's and characters' emotional relationship to it.

\section{References}

Alaimo, S. (2010). Bodily Natures: Science, Environment, and the Material Self. Bloomington: Indiana UP.

Bhabha, H. K. (1992). The World and the Home. Social text: Third World and Post-colonial Issues, 31(32), 141-153.

Birch, D., \& Hooper, K. (Eds.) (2012). The Concise Oxford Companion to English Literature. Oxford: Oxford University Press.

Bowles, P. (2005). The Sheltering Sky. New York: Harper Perennial.

Bowles, P. (2006 [1957]). Their Heads Are Green and Their Hands Are Blue. New York: Harper Perennial.

Caponi, G. D. (Ed.) (1993). Conversations with Paul Bowles. Jackson: UP of Mississippi.

Caponi, G. D. (Ed.) (1994). Paul Bowles: Romantic Savage. Carbondale: Southern Illinois University Press.

Caponi, G. D. (Ed.) (1994). Paul Bowles: Romantic Savage. Carbondale: Southern Illinois UP.

Cosgrove, D. E. (1998 [1984]). Social Formation and Symbolic Landscape. Madison: University of Wisconsin Press.

Dillon, M. (2000). You Are Not I: A Portrait of Paul Bowles. Berkeley: University of California Press.

Easterlin, N. (2010). Cognitive Ecocriticism: Human Wayfinding, Sociality, and Literary Interpretation. In L. Zunshine (Ed.), Introduction to Cognitive Cultural Studies (pp. 257-274). Baltimore: Johns Hopkins UP.

Fromm, H., \& Glotfelty, C. (Eds.) (1996). The Ecocriticim Reader: Landmarks in Literary Ecology. Athens: University of Georgia Press. 
Haynes, R. D. (1998). Seeking the Centre: The Australian Desert in Literature, Art and Film. New York: Cambridge University Press.

Hout, S. C. (2000). Grains of Utopia: The Desert as Literary Oasis in Paul Bowles's The Sheltering Sky and Wilfred Thesiger's Arabian Sands. Utopian Studies, 11(2), 112-136.

Lacey, R. K., \& Poole, F. (Eds.) (1996). Mirrors on the Maghrib: Critical Reflections on Paul and Jane Bowles and Other American Writers in Morocco. Delmar, N.Y.: Caravan Books.

Baichwal, J. (Director). (1998). Let It Come Down: The Life of Paul Bowles [Documentary Film]. New York, NY: Zeitgeist.

Maier, J. R. (1996). Desert Songs: Western Images of Morocco and Moroccan Images of the West. Albany: State University of New York P.

McInerney, J. (1993). Paul Bowles in Exile. In G. D. Caponi (Ed.), Conversations with Paul Bowles (pp. 180-192). Jackson: UP of Mississippi.

Melling, P. (2001). The American Adam: Salvation and Suicide. In V. Pâtea, \& M. E. Díaz, (Eds.), Critical Essays on the Myth of the American Adam (pp. 195-206). Salamanca: Ediciones Universidad de Salamanca.

Mossner, A. W. V. (2013). "Encountering the Sahara: Embodiment, Emotion, and Material Agency in Paul Bowles's The Sheltering Sky.”Interdisciplinary Studies in Literature and Environment, 20, 219-238.

Perlow, L. S. (2008). Out of Africa and South of the Border: Paul Bowles' Literary Work in the Western Tropics. Diss. Drew University. Ann Arbor: UMI, 2011. AAT3352195. Also [Online] Available: Google Books at http://books. google.com (January 10, 2017).

Pounds, W. (1985). Paul Bowles: The Inner Geography. New York: Peter Lang.

Schama, S. (1996). Landscape and Memory. London: Fontana.

Stewart, L. D. (1974). Paul Bowles: The Illumination of North Africa. Carbondale: Southern Illinois UP.

Tilley, C. (2006). Introduction: Identity, Place, Landscape and Heritage. Journal of Material Culture, 11(1-2), 732.

Wallace, K. R., \& Armbruster, K. (2001). Introduction: Why Go Beyond Nature Writing and Where To? In K. Armbruster, \& K. R. Wallace (Eds.), Beyond Nature Writing: Expanding the Boundaries of Ecocriticism (pp. 1-25). Charlottesville and London: University of Virginia Press. 